\title{
Photoinduced acyl transfer
}

\author{
Jean-Luc Débieux ${ }^{\mathrm{a}}$ and Christian G. Bochet ${ }^{\mathrm{a} *}$
}

\begin{abstract}
The acylation reaction occupies a central role in biochemistry and organic synthesis. On the one hand, it is by this very reaction that amino acids successively assemble to form peptides and proteins, and on the other hand it is a major synthetic method encompassing esterification, amidation, Friedel-Crafts reaction and many other processes routinely used both at the laboratory and the industrial scale. Photochemical activation is always an attractive alternative, because it is relatively mild (provided innocuous wavelengths are used), and no additional substance is added; thus no separation of the activator is necessary at the end of the process. In this paper, we briefly survey the most widely used methods of photoinduced acylations, and our own contribution to the field.
\end{abstract}

Keywords: acylation; amides; carbamates; esters; photochemistry

\section{INTRODUCTION}

The acylation reaction occupies a central role in biochemistry and organic synthesis. On the one hand, it is by this very reaction that amino acids successively assemble to form peptides and proteins, and on the other hand it is a major synthetic method encompassing esterification, amidation, Friedel-Crafts reaction and many other processes routinely used both at the laboratory and the industrial scale (Scheme 1).

Acylation can be viewed as the transfer of an acyl group from a donor to a carbon, oxygen or nitrogen nucleophile. Acyl donors are typically acid chlorides, acid anhydrides or activated esters, and the high reactivity of these reagents ensures reaction without particular activation. On the other hand, amides are relatively inert towards acyl transfer, and activation is usually required. Such an activation can arise from the addition of Lewis acids such as Ti(IV) complexes, ${ }^{[1]}$ enzymes, ${ }^{[2]}$ etc.

Photochemical activation is always an attractive alternative, because it is relatively mild (provided innocuous wavelengths are used), and no additional substance is added; thus no separation of the activator is necessary at the end of the process. A typical strategy for a photoinduced acylation involves an inert leaving group bound to the acyl group, ensuring little or no reactivity at the ground state (as an amide would do), which is photochemically converted into a reactive intermediate, of a reactivity similar to an acid halide, ready to be trapped by an incoming nucleophile (Scheme 2). In this paper, we briefly survey the most widely used methods of photoinduced acylations, and our own contribution to the field.

\section{N-ACYL-7-NITROINDOLINE DERIVATIVES}

$\mathrm{N}$-Acyl-5-bromo-7-nitroindoline $\mathbf{3}$ (Bni) was one of the first amides, that was identified as a photoactivable group, in the seminal work of Amit et al. ${ }^{[3]}$ Originally studied as protecting groups in peptide synthesis, amides $\mathbf{1}$ were converted into carboxylic acids 2 (Scheme 3, $\mathrm{NuH}=\mathrm{H}_{2} \mathrm{O}$ ) by photolysis in water-containing solvent mixtures. On the other hand, when carried out in methanol, the photolysis provided a methyl ester, thus proving the feasibility of a photoinduced acylation. Similarly, in the presence of concentrated ammonia, a benzamide was obtained (Scheme 3, $\mathrm{NuH}=\mathrm{NH}_{3}$ and $\mathrm{R}=\mathrm{Ph}$ ). At that time, large excesses of nucleophiles were required, and no ester was obtained when an equimolar of indoline derivative and alcohol were used.

Irradiations were usually performed at $350 \mathrm{~nm}$, but the reaction was proved possible with longer wavelengths, up to ca $420 \mathrm{~nm}$. Such long wavelengths have the benefit of limiting the risks of interaction with other potentially photosensitive groups such as aromatic side chains in amino acid residues.

Amit et al. also tested this reaction with a $\mathrm{N}$-acyl,5,7dinitroindoline, with similar good results, for the formation of both carboxylic acids and esters.

A few years later, this method was exploited by Pass, Amit and Patchornik to assemble peptides, in particular the neuroactive Leu-Enkephalin 4 (Scheme 4). ${ }^{[4]}$ The introduction of the Bni group on the amino acid proved, however, to be problematic. Several synthetic routes were studied, including indoline nitration after the acylation with the amino acid. ${ }^{[5]}$ Finally, the most practical procedure turned out to be heating the amino acid and the nitroindoline in toluene at $70^{\circ} \mathrm{C}$ in the presence of thionyl chloride. During the photoinduced coupling, the temperature was lowered to $-15^{\circ} \mathrm{C}$ to suppress partial racemization. This example showed for the first time that photoacylation could be a valuable tool for peptide synthesis.

A resin-bound version was recently developed by Nicolaou et al., in which the 7-nitroindoline was attached to a solid support (Scheme 5). ${ }^{[6]}$

If a high excess of amine is used (10 equiv.), this method allowed the preparation of amides in high yields (up to $95 \%$ ). Intramolecular versions provided six-membered lactames and 2-imidazolidinones with similarly high yields (70-90\%). On the other hand, the formation of larger rings was unsatisfactory.

Our laboratory elaborated an efficient and practical amine acylation reaction, providing amides by photoactivation of various $\mathrm{N}$-acyl-5,7-dinitroindolines (7) with only equimolar

\footnotetext{
* Correspondence to: C. G. Bochet, Department of Chemistry, University of Fribourg, Fribourg, Switzerland.

E-mail: christian.bochet@unifr.ch

a J.-L. Débieux, C. G. Bochet

Department of Chemistry, University of Fribourg, Fribourg, Switzerland
} 


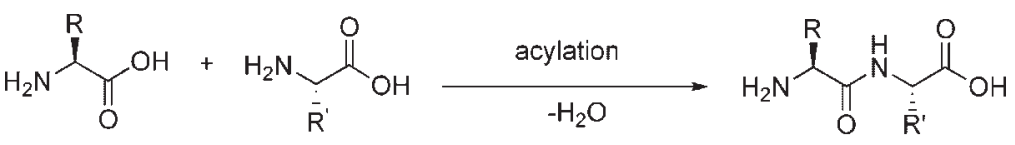

amino acid I amino acid II

peptide

Scheme 1.

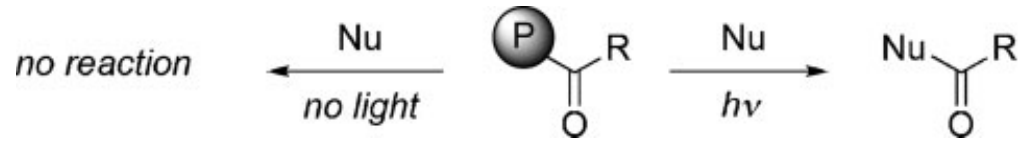

Scheme 2.<smiles>[R]C(=O)N1CCc2cc(Br)cc([N+](=O)[O-])c21</smiles>

$\mathrm{R}=\mathrm{CH}_{3}, \mathrm{C}_{7} \mathrm{H}_{15}, \mathrm{Ph}$

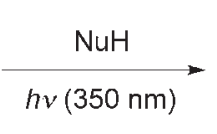

$h v(350 \mathrm{~nm})$

$\mathrm{NuH}=\mathrm{H}_{2} \mathrm{O}, \mathrm{NH}_{3}, \mathrm{MeOH}, \mathrm{RNH}_{2}$<smiles>O=[N+]([O-])c1cc(Br)cc2c1NCC2</smiles>

3

Scheme 3.

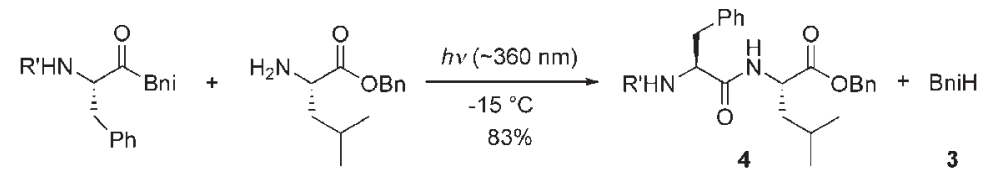

$R^{\prime}=\operatorname{Boc}-\operatorname{Tyr}(\mathrm{OBz} \mid)-\mathrm{Gly}-\mathrm{Gly}$

Scheme 4.

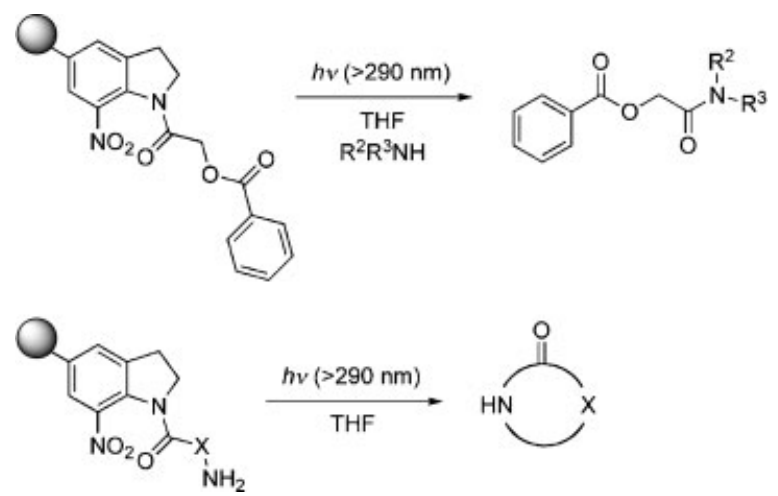

Scheme 5.

amounts of acylating species and amine (Scheme 6). ${ }^{[7]}$ Dinitroindoline (5, DniH) was directly acylated with the parent acid chloride $\mathbf{6}$ and a Lewis acid (aluminium trichloride).

Primary and secondary amines gave good to excellent yields, with the notable exception of very hindered amines (e.g. dicyclohexylamine) and poorly nucleophilic amines (e.g. anilines).
The formation of esters proved to be more problematic, mainly because alcohols are much poorer nucleophiles than amines. However, by using near-saturation concentrations and anhydrous acetonitrile as a solvent, we were able to acylate a broad range of alcohols. In fact, if the above-mentioned precautions were taken, primary, secondary and even tertiary alcohols reacted with one 
equivalent of the $\mathrm{N}$-acylated 5,7-dinitroindoline $\mathbf{7}$ to give esters in consistently high yields (Scheme 7). ${ }^{[8]}$ Interestingly, $3^{\prime}, 5^{\prime}$ dimethoxybenzoin 8 behaved perfectly well, which is surprising since $\mathbf{8}$ is itself a photolabile group for generating carboxylic acids. However, the working wavelength for the acyl transfer $(405 \mathrm{~nm})$ is sufficiently distant from that necessary for cleaving the benzoin $(300 \mathrm{~nm})$ to prevent interferences. This is a case of partial chromatic orthogonality. ${ }^{[9,10]}$ The latter concept describes the capacity of different photolabile protecting groups to be photolyzed at different wavelengths without mutual interference and in any chronological sequence (Scheme 8). ${ }^{[1]}$

One of the problems for the transfer of more complex acyl groups than just alkylanoyl or benzoyl groups is the preparation of the indoline itself. As mentioned above, the direct acylation of 5,7-dinitroindoline $\mathbf{5}$ is possible only in the presence of strong Lewis acid, conditions incompatible with, say, amino acids. For this reason, we had to elaborate an alternative route for the preparation of photoactivable amino acids. Thus, phenethylamine hydrochloride $\mathbf{9}$, with a nucleophilic nitrogen atom is acylated under classical conditions with an amino acid derivative, and then cyclyzed in a Pd-catalyzed amide arylation under microwave irradiation to give the indolines $\mathbf{1 1}$ in satisfactory yields (Scheme 9). ${ }^{[12]}$

Michael et al. recently synthesized $N$-glycosylasparagines with this method under mild conditions, thus avoiding the formation of aspartimide by-products (Scheme 10). ${ }^{[13]}$ Glycopeptides are usually prepared by the condensation of a glycosamine with an activated form of aspartic acid-containing peptide. However, the presence of a base can provoke the formation of aspartimide by-products. The photoinduced transamidation gave the desired products in good yields under neutral conditions (61-64\%), using nearly equimolar mixtures of both reactants. $\mathrm{N}$-Glycosylglutamines were also prepared in a similar manner, from glycosylamines and 1-C-aminomethylglycosides. ${ }^{[14]}$

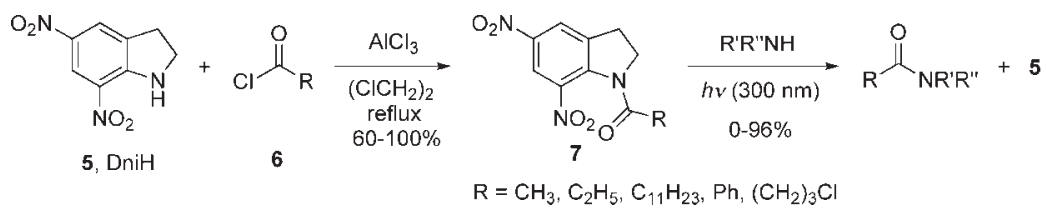

Scheme 6 .

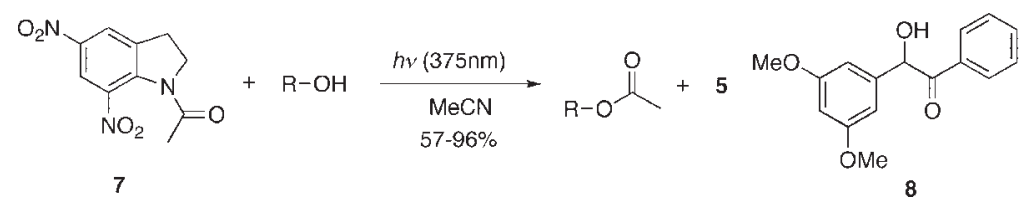

Scheme 7.

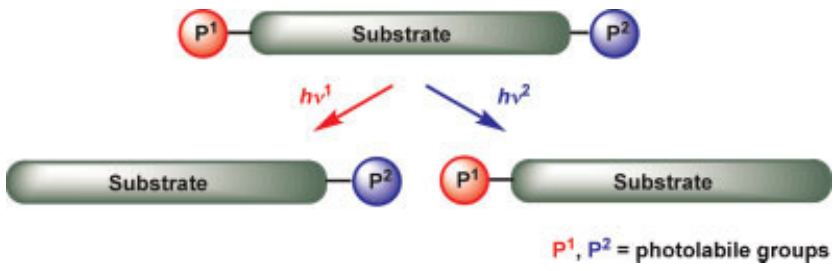

Scheme 8.

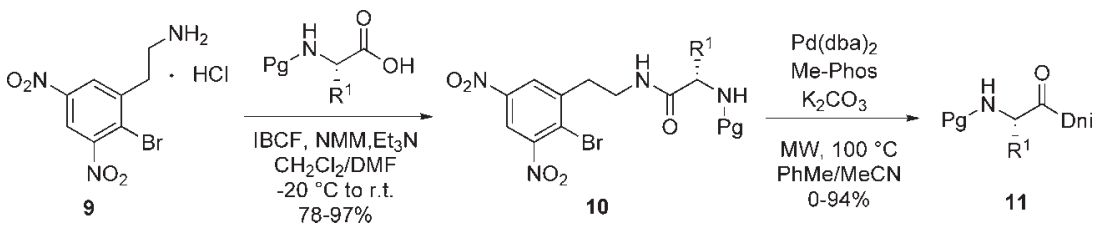

Scheme 9.

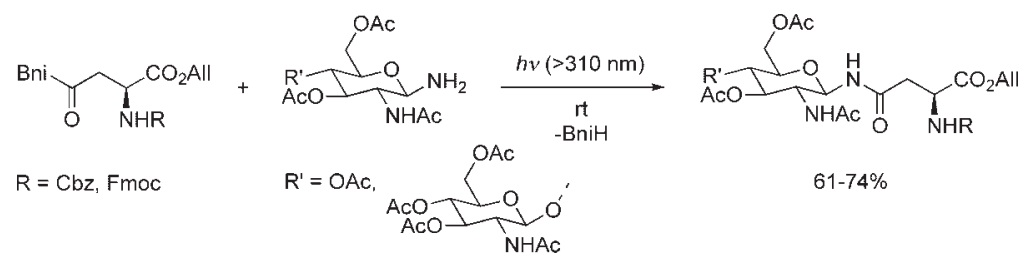

Scheme 10. 


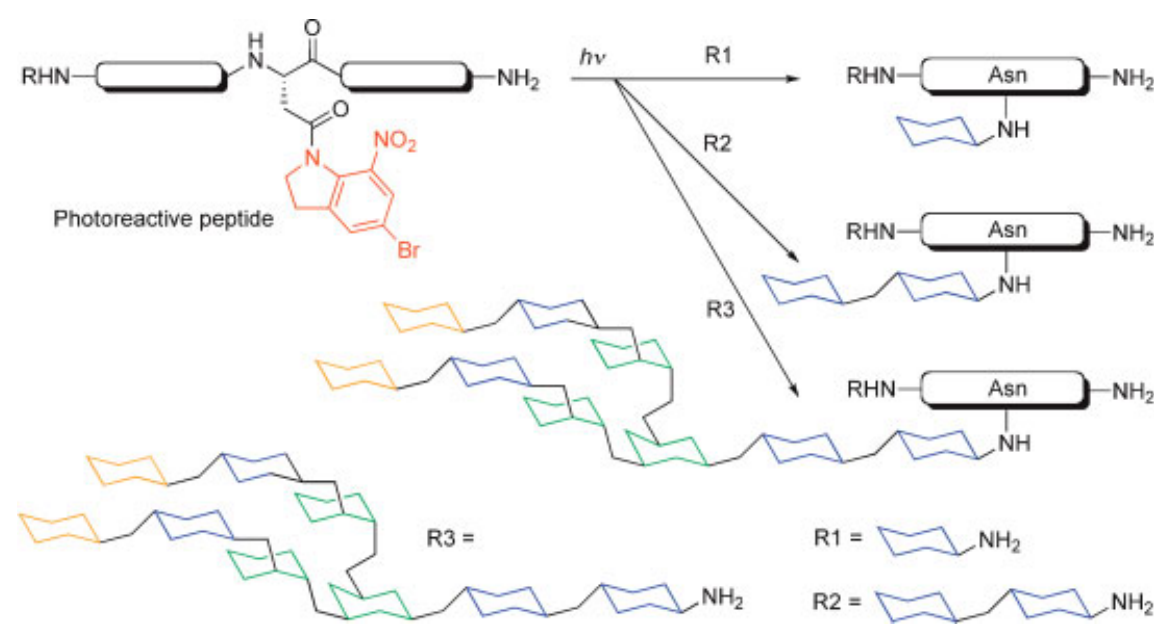

Scheme 11.

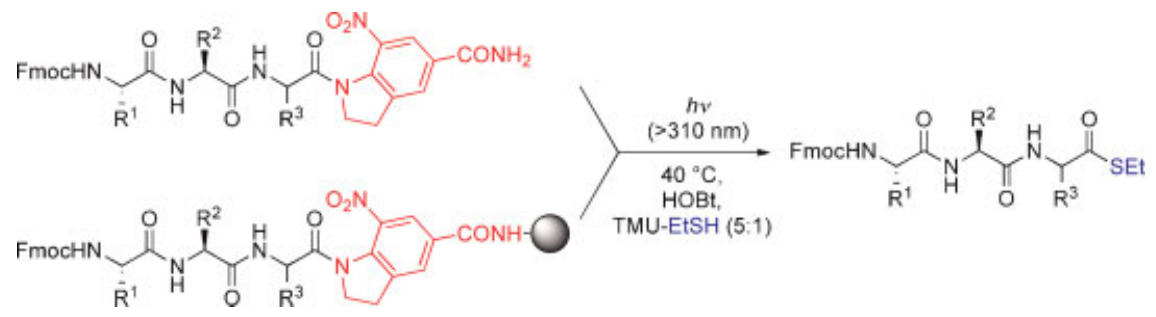

Scheme 12.

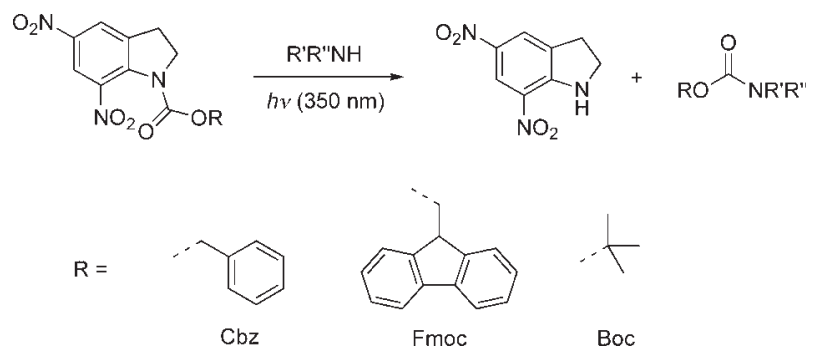

Scheme 13.

The same authors applied this strategy for the convergent preparation of complex $\mathrm{N}$-glycopeptides, placing the Bni group at the terminus of asparagines (Scheme 11). ${ }^{[15]}$ It is worth noting that this method requires two equivalents of HOBt and molecular sieves for the more complex glycopeptides.

Furthermore, they extended this strategy to new solid supports with dual functions, thus allowing the preparation of peptides with a photoreactive C-terminus, which can be derivatized by UV-irradiation in the presence of nucleophiles. For example, in the presence of ethyl mercaptan, peptide thioesters were obtained in ca $60 \%$ yields with less than $5 \%$ epimerization (Scheme 12). ${ }^{[16]}$

Despite their ubiquity in natural substances, amides are relatively unpractical as protecting groups, mainly because of their high hydrolytic stability. On the other hand, carbamates are much more versatile, in particular if the substituents endow them with reactivity under very specific conditions, such as a benzyl group $\left(\mathrm{Cbz}\right.$, removed by hydrogenolysis, e.g. $\left.\mathrm{H}_{2} / \mathrm{Pd}-\mathrm{C}\right)$, a fluorenylmethyl group (Fmoc, removed in basic media, such as in piperidine) or a tert-butyl group (Boc, removed in acidic media, such as in trifluoroacetic acid). Our laboratory developed a variation of the nitroindoline-based photoacylation for the synthesis of carbamates under very smooth conditions, using equimolar mixtures of both reactants (Scheme 13). ${ }^{[17]}$

Thus, primary and non-hindered secondary amines were efficiently protected by converting them into their benzyloxycarbonyl (Cbz) and 9-fluorenylmethoxycarbonyl (Fmoc) derivatives, whereas hindered or non-nucleophilic amines (such as anilines) failed to react in significant yields. On the other hand, tert-butoxycarbonyl (Boc) derivatives were obtained only in low yields.

Several mechanistic studies were carried out on $\mathrm{N}$-acyl-7nitroindolines. According to Wan, Corrie et al., ${ }^{[18]}$ two different pathways are possible. Following the formation of the common intermediate 13 by photochemical excitation, classical nucleophilic attack to the activated carboxyl group followed by protonation leads to the expected product 16. This pathway 


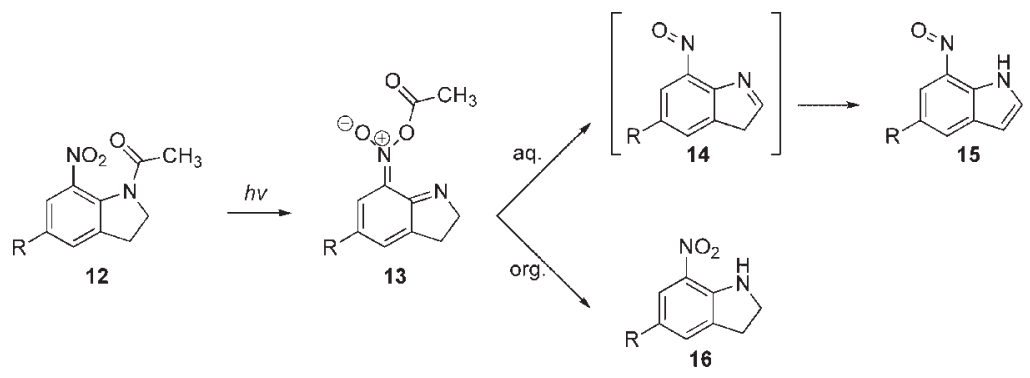

Scheme 14

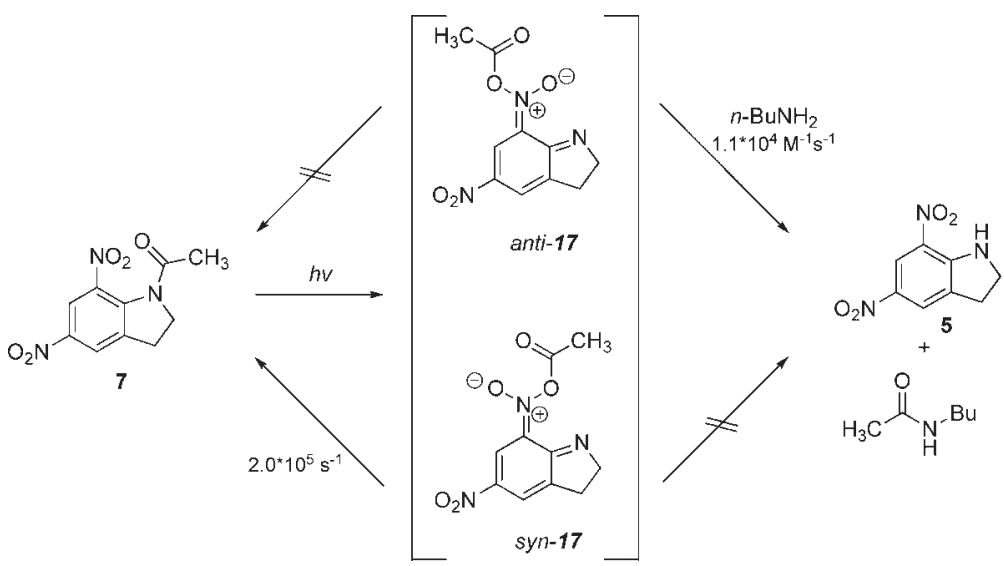

Scheme 15.

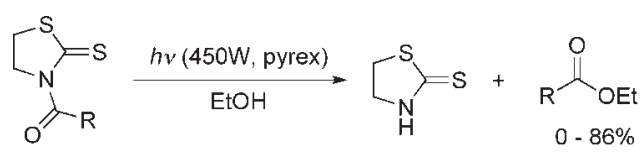

18

19

Scheme 16

occurs in organic solvents. However, in aqueous media, acetate elimination occurs, leading to acetic acid and a $3 \mathrm{H}$-nitrosoindoline $\mathbf{1 4}$, which tautomerizes into the isolable nitrosoindole 15 (Scheme 14).

In collaboration with the group of Prof. Toscano at Johns Hopkins University in Baltimore, we studied the reaction in organic media by time-resolved infrared spectroscopy. ${ }^{[19]}$ We concluded that initial photolysis leads to the two noninterconvertible syn and anti nitronic acetic anhydrides $\mathbf{1 7}$ (Scheme 15). While the syn conformer relaxes readily back to the starting material, the longer-lived anti conformer can be trapped by a nucleophile ( $n$-butylamine in this study). This mechanistic scheme was backed up both by infrared spectroscopy and by DFT calculations. Although additional studies might be required, there is little doubt on the implication of a O-acyl-nitro intermediate.

\section{N-ACYLTHIAZOLIDINE-2-THIONE DERIVATIVES}

Another class of compounds that is able to undergo photoinduced acyl transfer is the thiazolidine-2-thiones 18. Relatively inert in the absence of light, irradiation promotes the transfer of the acyl group to a nucleophile (solvent), as shown in Scheme $16^{[20]}$

The reaction is compatible with a variety of side chains $R$, but the presence of an $\alpha$-hydrogen atom is required. This observation suggested a Norrish-type II mechanism, leading to a ketene intermediate, which is then trapped by the nucleophile (Scheme 17). Indeed, substrates bearing a chiral center at the $\alpha$ position showed complete racemization. Thus, this is not, strictly speaking, a photoinduced acyl transfer, but a thermal addition.

Actually, $\mathrm{N}$-acylthiazolidine-2-thiones react with amines also in the absence of light, leading to amides at room temperature (Scheme 18). ${ }^{[21]}$ Indeed, the thiazolidine-2-thione is a passable leaving group, which sufficiently activates the carboxyl for a reaction with better nucleophiles, even in the dark. In such a case, the nature of the acyl group has little influence on the efficiency of the process; on the other hand, the reaction rate is strongly influenced by the nucleophilicity and the steric bulk of the amine.

Subsequent work showed that analogs 20-22 ( $\mathrm{N}$-acyloxazolidine-2-thione 20, $\mathrm{N}$-acylindoline-2-thione 21, and $\mathrm{N}$-acylindoline-2-one 22) react similarly in the presence of an alcohol (methanol or ethanol) (Fig. 1). ${ }^{[22,23]}$ 
<smiles>[R]C(=O)N1CCOC1=S</smiles>

20<smiles>[R]C(=O)N1C(=S)C(C)(C)c2ccccc21</smiles>

21<smiles>[R]C(=O)N1C(=O)C(C)(C)c2ccccc21</smiles>

22

Figure 1. Other photoreactive small heterocycles

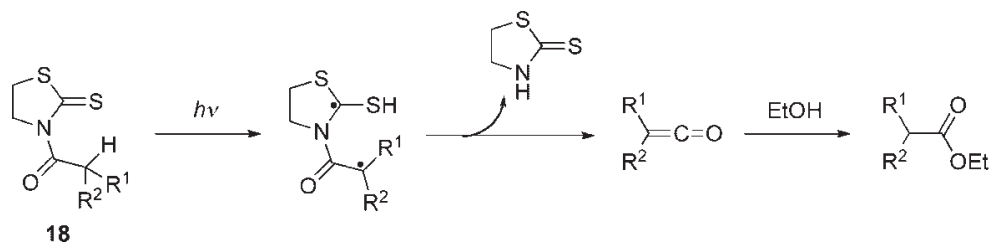

Scheme 17.

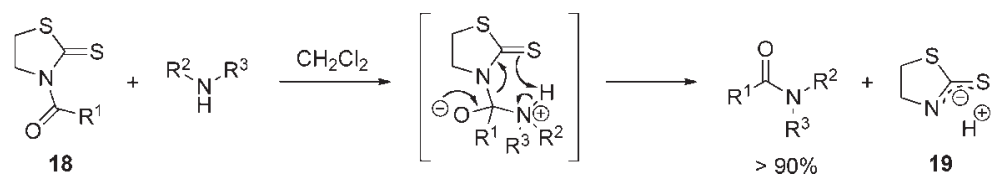

Scheme 18.

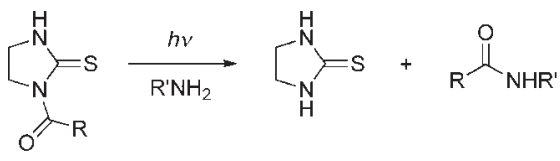

23

24

Scheme 19

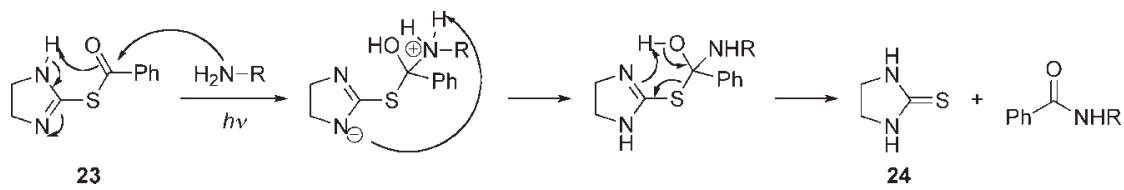

Scheme 20.

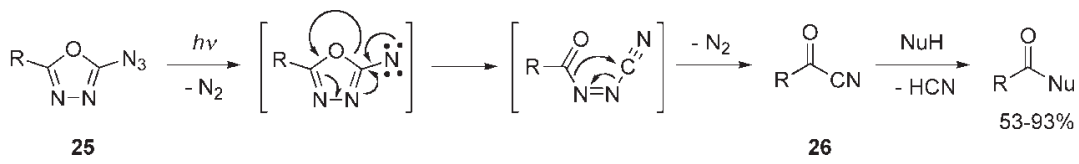

Scheme 21.

In the specific case of $\mathrm{N}$-acylimidazoline-2-thione $\mathbf{2 3}$, the structural modification brings a significant difference in the reactivity: acylation also occurs with a phenyl side chain (no $\alpha$-hydrogen) (Scheme 19). ${ }^{[24]}$

Therefore, the reaction cannot proceed via a ketene intermediate, and the following mechanism was proposed (Scheme 20). The reaction proceeds efficiently with primary amines, anilines and amino acids.

\section{5-AZIDO-1,3,4-OXADIAZOLES DERIVATIVES}

A related reaction was described by Confalone and Woodward in $1983 .^{[25]}$ Photolysis of 5-azido-1,3,4-oxadiazole 25 generated an acyl cyanide (26), which is then trapped by a nucleophile or the solvent. This heterocycle is thus a masked carboxyl group (Scheme 21). The proposed mechanism implies the photoinduced extrusion of dinitrogen from $\mathbf{2 5}$ to give a nitrene, which 


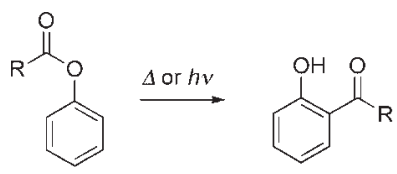

Scheme 22 .

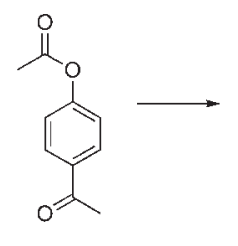

27

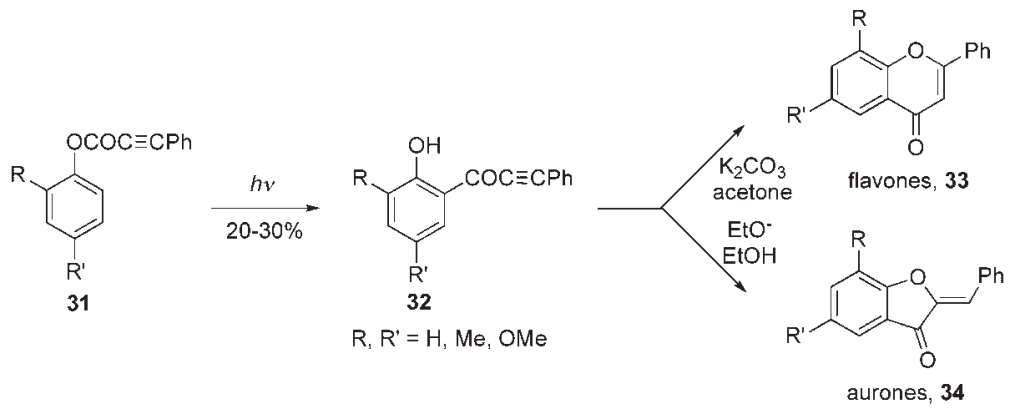

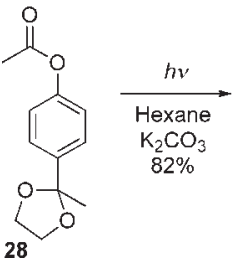

Scheme 23.<smiles>CC(=O)c1cc(C2(C)OCCO2)ccc1O</smiles>

29<smiles>CC(=O)c1ccc(O)c(C(C)=O)c1</smiles>

30

Scheme 24.

spontaneously rearranges to an acyl cyanide. This process has the notable advantage of producing only gaseous side products, facilitating the product purification; on the other hand, the high toxicity of HCN might be a significant drawback in specific applications. Furthermore, cumbersome preparation of oxadiazoles might limit the use of these derivatives as a protecting group.

This reaction was tested on various acyl groups, including amino acids. In typical examples, the nucleophile was not present during irradiation, but added later, in some cases after the isolation of the acyl cyanide intermediate; however, if the reaction is carried out in a benzene/ethanol mixture (1:1), ethyl esters are directly obtained.

\section{PHOTO-FRIES REARRANGEMENT}

The Fries rearrangement is the migration of a $\mathrm{C}(\mathrm{O}) \mathrm{R}$ group from the oxygen of an acylated phenol derivative to the ortho or para carbon (Scheme 22).

This process normally requires high temperatures and/or Lewis acids (such as aluminium trichloride), ${ }^{[26-28]}$ but UV irradiation allows the reaction to occur at much lower temperatures. Homolytic scission of the $\mathrm{O}-\mathrm{C}(\mathrm{O}) \mathrm{R}$ bond probably leads to an ambident phenoxy radical (an enoyl radical), which can irreversibly recombine at the $\mathrm{C}$-terminus giving the observed products. $^{[29]}$

Electron withdrawing substituents (such as acyl groups) on the aromatic ring usually inhibit this rearrangement, but suitable protection allowed the polyacylation of phenols. ${ }^{[30,31]}$ This strategy was used for the conversion of $p$-hydroxyacetophenone 27 into hydroxydiketone $\mathbf{3 0}$ (Scheme 23).

When the acyl group bears another functionality (double or triple bond, hydroxyl, carbonyl), its reaction with the newly formed $\mathrm{OH}$ group can be exploited for the assembly of heterocyclic systems. For example, photolysis or phenylpropiolic aryl esters $\mathbf{3 1}$ leads first to ortho-hydroxyaryl phenylethynyl ketones 32, which can then follow two pathways, depending on the conditions. In acetone containing potassium carbonate, flavones $\mathbf{3 3}$ are formed by a 6-endo-dig process. On the other hand, in ethanol containing sodium ethoxide, a 5-exo-dig process leads to aurones 34 as major products (Scheme 24). ${ }^{[32]}$

Biphasic conditions (liquid/liquid) are commonly used to increase the efficiency of photo-Fries reactions. For example, para-methoxyphenyl esters of $\alpha, \beta$-unsaturated carboxylic acids (35) undergo a photochemical rearrangement followed by basic cyclization to give moderate overall yields of 4-chromanones 36. In a biphasic system (benzene/aqueous sodium hydroxide), chromanones are directly obtained in excellent yields (Scheme 25). ${ }^{[33]}$ Further reduction/dehydration led to $2 \mathrm{H}$-chromenes 37 , which are interesting due to their bioactivity against juvenile hormones.

An industrial application of the photo-Fries rearrangement is found in polymeric imaging systems. ${ }^{[34]}$ Photolithography is based on the possibility of selectively dissolving exposed or non-exposed surface on a polymeric film. Since all photo-Fries products are phenols, they can easily be washed away with aqueous base, whereas unchanged starting material remains insoluble (Scheme 26). ${ }^{[35]}$ 


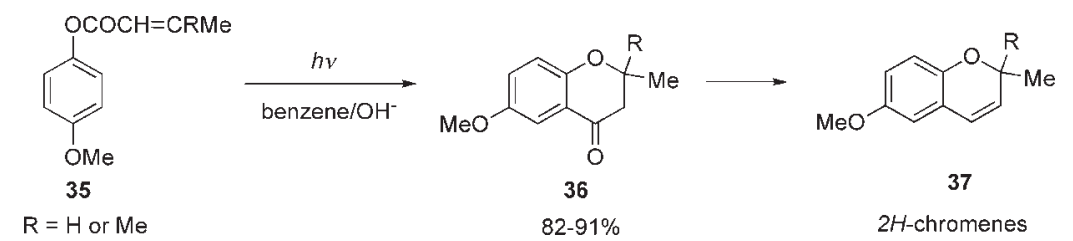

Scheme 25.

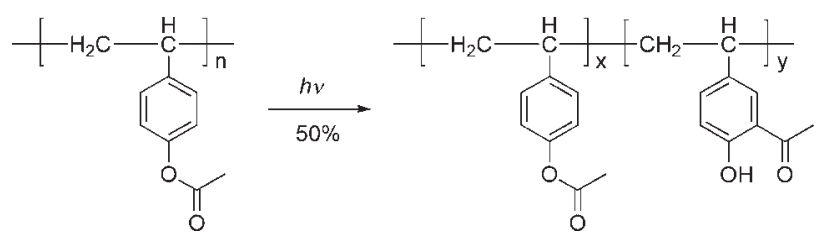

Scheme 26.

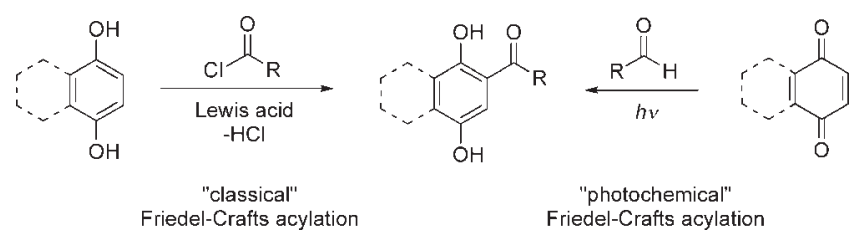

Scheme 27

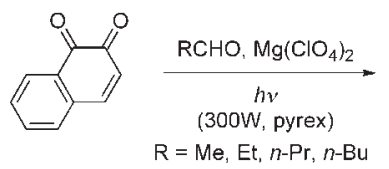

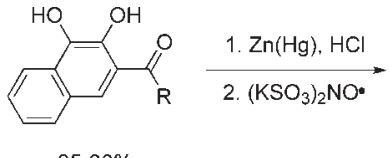

$25-30 \%$

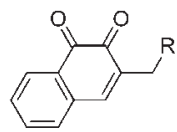

$52-60 \%$

Scheme 28.

\section{PHOTO-FRIEDEL-CRAFTS ACYLATION}

Acylated quinone derivatives are usually prepared by FriedelCrafts acylation with moderate to good yields. ${ }^{[36-38]}$ However, this classical method suffers from the use of equimolar amounts of corrosive acid chlorides and strong Lewis acids (usually aluminum trichloride), release of harmful side products (in particular gaseous hydrochloric acid), and some restrictions on the structure of the starting material. The photochemical reaction between quinones and aldehydes represents a mild and efficient alternative, often called 'photo-Friedel-Crafts' reaction (Scheme 27). ${ }^{\text {[39] }}$

In this process, hydrogen abstraction on an aldehyde by an electronically excited quinone generates acyl radicals, which add to a second quinone (this time in its electronic ground state) in a free radical chain reaction. An alternate mechanism with a caged recombination of the first radical pair has been discussed by Maruyama et al. ${ }^{[40-43]}$ On the other hand, earlier work by Bruce et al. ${ }^{[44]}$ and recent studies favor the free radical mechanism. ${ }^{[45]}$

First reported in 1891 by Klinger (who exposed the reactant to sunlight for several months), ${ }^{[46,47]}$ this reaction attracted little attention within the synthetic community until 1992, when Kraus et al. used it at a multigram scale. ${ }^{[48]}$ Takuwa and Kai used magnesium perchlorate to improve the photochemical reaction for the preparation of 3-alkyl-1,2-naphthoquinones, in order to overcome the high sensitivity of 1,2-naphthoquinones to heat and acids (Scheme 28). ${ }^{[4]}$ The acylated hydroquinones thus obtained were then easily converted into alkylated quinones by a Clemmensen reduction/Fremy's salt oxidation sequence.

Maruyama and Naruta reported an efficient synthetic route for $\alpha$ - and $\beta$-lapachones and their analogues, showing antimicrobial and antitumoral activity, by the photochemical addition of 2-alkenoyl groups to a 1,4-naphthoquinone (Scheme 29). ${ }^{[50]}$

Also, Kobayashi et al. developed a simple access to benzo[b]xanthene-6,11,12-trione using a photoinduced naphthoquinone acylation (Scheme 30$){ }^{[51]}$ Subsequent oxidative cyclization with an excess of silver oxide gave xanthenequinone with moderate overall yields.

The same authors also reported the synthesis of benzodithiophene-4,8-dione derivatives 39 from 4,7-dioxo-4,7-dihydrobenz[b]thiophene-2-carboxylates 38 (Scheme 31$).{ }^{[52]}$ The route starts with a regioselective acylation at the position 5 , with irradiation of a series of aldehydes, followed by oxidation with silver oxide. The acylated benzothiophenequinones were then converted in a one-pot sequence (treatment with mercaptoacetates followed by cyclization with 1-trimethylsilylimidazole and oxidation with ceric ammonium nitrate).

Recently, benzodithiophene-4,5-diones were prepared from benzo[b]thiophene-4,5-diones in a similar manner. ${ }^{[53]}$

The strong antibiotic activity of pyrononaphthoquinones (e.g. frenolicine $\mathrm{B}$ or kalafungine) prompted a growing attention to their synthesis. Kraus et al. applied a photoacylation of 5,8-dimethoxy-1,4-naphthoquinone (using $15 \mathrm{~mol}-\%$ of benzo- 


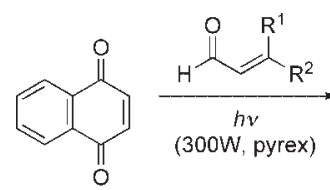<smiles>[R]/C(C)=C/C(=O)c1cc(O)c2ccccc2c1O</smiles><smiles>[R]C1(C)CCc2cc(O)c3ccccc3c2O1</smiles><smiles>[R]C1([R])CCC2=C(O1)C(=O)c1ccccc1C2=O</smiles><smiles>[R]C1([R])CCC2=C(O1)c1ccccc1C(=O)C2=O</smiles>

Scheme 29.<smiles>[R]C1=CC(O)C(C=O)C=C1[R]</smiles><smiles>C1CCCC1</smiles><smiles>[R]OC(=O)c1sc2c(c1[R])C(=O)C=CC2=O</smiles>

38<smiles>[R]c1cc(O)c(C(=O)c2cc(O)c3ccccc3c2O)cc1[R]</smiles><smiles>[R]c1cc2oc3c(c(=O)c2cc1[R])C(=O)c1ccccc1C3=O</smiles>

Scheme 30 .

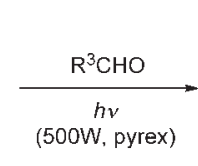
500 W, pyrex

$R^{3}$<smiles>[R]C(=O)c1cc(O)c2sc(C(=O)OCC)c(O)c2c1[R]</smiles>

$33-54 \%$<smiles>[R]C(=O)c1sc2c([R])c3c(=O)cc(C([R1])=O)c(=O)c=3c(=O)c1-2</smiles>
THF,

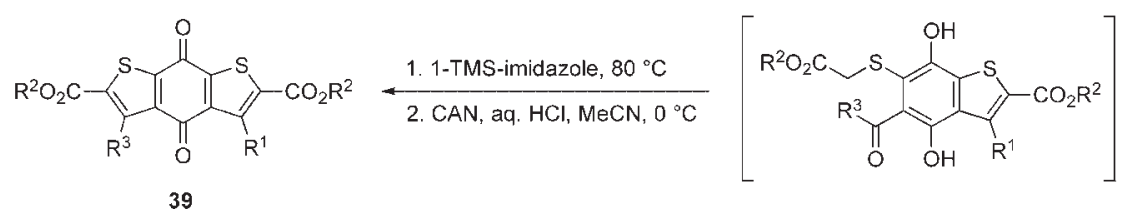

Scheme 31.<smiles>COc1ccc(OC)c2c1C(=O)C=CC(=O)C2=O</smiles><smiles>COc1ccc(OC)c2c(O)c(C(C)=O)cc(O)c12</smiles>

$64 \%$<smiles>COc1ccc(OC)c2c(O)c3c(c(O)c12)C(C)O[C@@H]1CC(=O)O[C@@H]31</smiles>

Kalafungin<smiles>COc1ccc(OC)c2c3c(c(C(C)=O)c(OC)c12)C1OC(=O)CC1O3</smiles>

CAN

$\mathrm{Et}_{3} \mathrm{SiH}, \mathrm{BF}_{3}$<smiles>COc1ccc(OC)c2c(OC)c3c(c(O)c12)C(C)(O)O[C@H]1CC(=O)O[C@@H]31</smiles>

Scheme 32. 


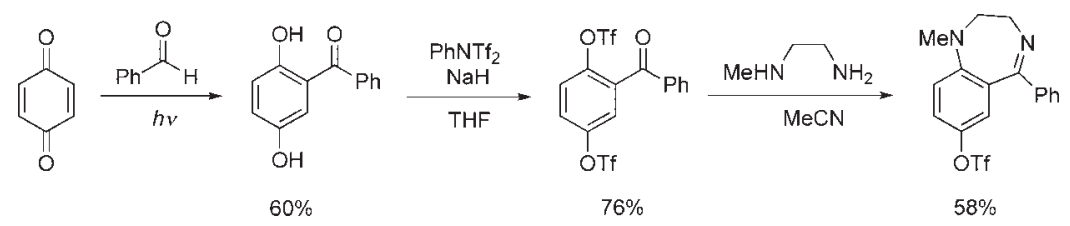

Scheme 33.

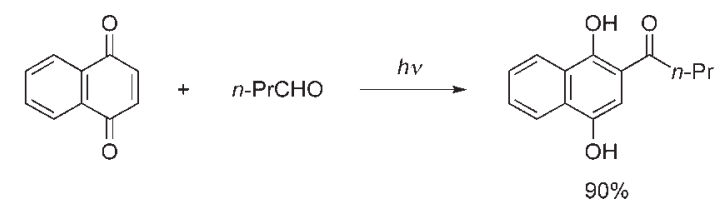

Scheme 34.

phenone as a sensitizer) for the synthesis of kalafungin (Scheme 32). ${ }^{[36-38]}$

Bruce et al. used the photochemical acylation for the assembly of a benzodiazepine skeleton (Scheme 33). ${ }^{[54]}$

The most spectacular use of the photoinduced acylation was demonstrated by Mattay et al. on a large scale using solar light (Scheme 34). ${ }^{[55-60]}$ Irradiation of a solution of 1,4naphthoquinone in tert-butanol/acetone $(500 \mathrm{~g})$ with butyraldehyde in a $24 \mathrm{~m}^{2}$ mirror system for 3 days (Germany, August 1996) gave the acylated product in $90 \%$ yields without major side products. During the reaction, 300 moles of photons (between 300 and $500 \mathrm{~nm}$, in the major absorption range of 1,4-quinones) were collected.

\section{CONCLUSION}

There are two ways in which a synthetic transformation can fuel interest for further study. Either it is very narrow in scope, but it allows a transformation that no other process is capable of achieving and can be used for the preparation of important compounds, or it provides a simple transformation, very robust in terms of functional groups and experimental conditions tolerance and very broad in scope. From this brief account, it becomes apparent that the photoinduced acyl transfer belongs to both categories. Simple acylation of a nucleophile with nitroindoline derivatives clearly belongs to the latter category, whereas the other reactions such as the photo Friedel-Crafts or the Fries rearrangement belong to the former. Therefore, one can only look forward to more studies, both mechanistic and synthetic, which should lead to a better understanding of the process and to more applications.

\section{REFERENCES}

[1] L. E. Fisher, J. M. Caroon, S. R. Stabler, S. Lundberg, S. Zaidi, C. M. Sorensen, M. L. Sparacino, J. M. Muchowsky, Can. J. Chem. 1994, 72, 142-145.

[2] B. Schulze, E. De Vroom, in: Enzyme Catalysis in Organic Synthesis, 2nd edn (Eds: K. Drauz, H. Waldmann), Wiley-VCH, Weinheim, 2002, 716-740.

[3] B. Amit, D. A. Ben-Efraim, A. Patchornik, J. Am. Chem. Soc. 1976, 98 , 843-844.

[4] S. Pass, B. Amit, A. Patchornik, J. Am. Chem. Soc. 1981, 103, 7674-7675.
[5] G. Goissis, B. W. Erickson, R. B. Merrifield, Peptides: Proc. Amer. Pept. Symp. 5th, 1977, 559-561.

[6] K. C. Nicolaou, B. S. Safina, N. Winssinger, Synlett, 2001, 900-903.

[7] C. Helgen, C. G. Bochet, Synlett, 2001, 1968-1970.

[8] J. L. Débieux, A. Cosandey, C. Helgen, C. G. Bochet, Eur. J. Org. Chem. 2007, 2073-2077.

[9] C. G. Bochet, Angew. Chem. Int. Ed. Engl. 2001, 40, 2071-2073.

[10] A. Blanc, C. G. Bochet, J. Org. Chem 2002, 67, 5567-5577.

[11] C. G. Bochet, Synlett 2004, 2268-2274.

[12] J. L. Débieux, C. G. Bochet, J. Org. Chem. 2009, 74, 4519-4524.

[13] K. Vízvárdi, C. Kreutz, A. S. Davis, V. P. Lee, B. J. Philmus, O. Simo, K. Michael, Chem. Lett. 2003, 32, 348-349.

[14] O. Simo, V. P. Lee, A. S. Davis, C. Kreutz, P. H. Gross, P. R. Jones, K. Michael, Carbohydr. Res. 2005, 340, 557-566.

[15] C. M. Kaneshiro, K. Michael, Angew. Chem. Int. Ed. 2006, 45, 1077-1081.

[16] T. J. Hogenauer, Q. Wang, A. K. Sanki, A. J. Gammon, C. H. L. Chu, C. M. Kaneshiro, Y. Kajihara, K. Michael, Org. Biomol. Chem. 2007, 5, 759-762.

[17] C. Helgen, C. G. Bochet, J. Org. Chem. 2003, 68, 2483-2486.

[18] J. Morrison, P. Wan, J. E. T. Corrie, G. Papageorgiou, Photochem. Photobiol. Sci. 2002, 1, 960-969.

[19] A. D. Cohen, C. Helgen, C. G. Bochet, J. P. Toscano, Org. Lett. 2005, 7, 2845-2848.

[20] L. P. J. Burton, J. D. White, Tetrahedron Lett. 1980, 21, 3147-3150.

[21] Y. Nagao, K. Seno, K. Kawabata, T. Miyasaka, S. Takao, E. Fujita, Tetrahedron Lett. 1980, 21, 841-844.

[22] M. Sakamoto, S. Watanbe, T. Fujita, H. Aoyama, Y. Omote, J. Chem. Soc., Perkin Trans. 1 1991, 2541-2545.

[23] T. Nishio, M. Oka, Helv. Chim. Acta 1997, 80, 388-397.

[24] E. Purushothaman, Indian J. Heterocycl. Chem. 1997, 7, 93-96.

[25] P. N. Confalone, R. B. Woodward, J. Am. Chem. Soc. 1983, 105, 902-906.

[26] A. H. Blatt, Org. React. 1942, 1, 342.

[27] R. Martin, Org. Prep. Proced. Int. 1992, 369.

[28] W. Kantlehner, Eur. J. Org. Chem. 2003, 2530-2546.

[29] D. Bellus, Adv. Photochem. 1971, 8, 109-159.

[30] H. Garcia, R. Martinez-Utrilla, M. A. Miranda, Tetrahedron 1985, 41, 3131-3134.

[31] H. Garcia, M. A. Miranda, J. Primo, J. Chem. Res. (S) 1986, 100101.

[32] H. Garcia, S. Iborra, J. Primo, M. A. Miranda, J. Org. Chem. 1986, 51, $4432-4436$

[33] J. Primo, R. Tormo, M. A. Miranda, Heterocycles, 1982, 19, 1819-1822.

[34] T. G. Tessier, J. M. J. Frechet, C. G. Willson, H. Ito, Am. Chem. Soc. Symp. Ser. 1984, 266, 269-292.

[35] J.-M. J. Frechet, T. G. Tessier, C. G. Willson, H. Ito, Macromolecules 1985 , $18,317-321$.

[36] G. A. Olah, Friedel-Crafts and Related Reactions (Ed.: G. A. Olah), Wiley, New York, 1963, 1, 91-169.

[37] P. H. Gore, Friedel-Crafts and Related Reactions (Ed.: G. A. Olah), Wiley, New York, 1964, 3, p. 1-381.

[38] P. H. Gore, Chem. Ind. (London) 1974, 727-731. 
[39] G. A. Kraus, H. Maeda, P. Lui, A. Melekhov, Y. Lu, Green Chemistry: Frontiers in Benign Chemical Syntheses and Processes (Eds: P. T. Anastas, T. C. Williamson), Oxford University Press, Oxford, 1998, 72-86.

[40] K. Maruyama, Y. Miyagi, Bull. Chem. Soc. Jpn. 1974, 47, 1303.

[41] A. Takuwa, O. Soga, K. Maruyama, J. Chem. Soc., Perkin Trans. 2 1985, 409.

[42] K. Maruyama, A. Takuwa, S. Matsukiyo, O. Soga, J. Chem. Soc., Perkin Trans. 1 1980, 1414.

[43] K. Maruyama, H. Sakurai, T. Otsuki, Bull. Chem. Soc. Jpn. 1977, 50, 2777.

[44] J. M. Bruce, E. Cutts, J. Chem. Soc. C 1966, 449-4458.

[45] C. Schiel, Ph. D. Thesis, University of Bielefeld: Bielefeld, 2001

[46] H. Klinger, O. Standke, Ber. Dtsch. Chem. Ges. 1891, 24, 1340-1346.

[47] H. Klinger, W. Kolvenbach, Ber. Dtsch. Chem. Ges. 1898, 31, $1214-1216$.

[48] G. A. Kraus, P. Liu, Tetrahedron Lett. 1994, 35, 7723; G. A. Kraus, M. Kirihara, J. Org. Chem. 1992, 57, 3256.
[49] A. Takuwa, K. Ryoji, Bull. Chem. Soc. Jpn. 1990, 63, 623-6625.

[50] K. Maruyama, Y. Naruta, Chem. Lett. 1977, 847-850.

[51] K. Kobayashi, A. Matsunaga, M. Mano, O. Morikawa, H. Konishi, Heterocycles 2002, 57, 1915-1918.

[52] K. Kobayashi, T. Ogata, K. Miyamoto, O. Morikawa, H. Konishi, Heterocycles 2003, 60, 1689-1695.

[53] K. Kobayashi, T. Ogata, D. Nakamura, O. Morikawa, H. Konishi, Heterocycles 2006, 68, 1709-1714.

[54] G. A. Kraus, H. Maeda, Tetrahedron Lett. 1994, 35, 9189-9190.

[55] C. Schiel, M. Oelgemöller, J. Mattay, J. Inf. Rec. 1998, 24, 257-260.

[56] C. Schiel, M. Oelgemöller, J. Mattay, Synthesis 2001, 1275-1279.

[57] C. Schiel, M. Oelgemöller, J. Ortner, J. Mattay, Green Chem. 2001, 3, 224-228.

[58] M. Oelgemöller, C. Schiel, J. Mattay, R. Fröhlich, Eur. J. Org. Chem. 2002, 2465-2474.

[59] P. Esser, B. Pohlmann, H.-D. Scharf, Angew. Chem. Int. Ed. Engl. 1994, 33, 2009-2023.

[60] K.-H. Funken, J. Ortner, Z. Phys. Chem. 1999, 213, 99-105. 